\title{
Meta-analysis of the methylenetetrahydrofolate reductase C677T polymorphism and susceptibility to pre-eclampsia
}

\author{
Xiao-ping Xia ${ }^{1,2}$, Wei-wei Chang ${ }^{3}$ and Yun-xia Cao ${ }^{1}$ \\ A number of studies have investigated the association between the methylenetetrahydrofolate reductase (MTHFR) C677T \\ polymorphism and the risk of pre-eclampsia (PE) in various populations and have delivered inconsistent results. Therefore, \\ this meta-analysis of 36 case-control studies, comprising 4253 PE cases and 4950 controls, were assessed to evaluate \\ a possible association. The pooled results showed that the MTHFR C677T polymorphism was significantly associated with \\ $\mathrm{PE}(P=0.03$, odds ratio $(\mathrm{OR})=1.25,95 \%$ confidence interval $(\mathrm{CI})=1.02-1.54$, for the additive comparison; $P=0.04$, \\ $\mathrm{OR}=1.14,95 \% \mathrm{CI}=1.01-1.29$, for the dominant genetic model). The results of the subgroup analysis showed that MTHFR \\ 677T had the effect of increasing the PE risk for the recessive genetic model $(P<0.0001,0 R=1.76,95 \% \mathrm{CI}=1.33-2.33$, \\ $\left.P_{\text {heterogeneity }}=0.28\right)$, the additive comparison $\left(P=0.002,0 R=2.09,95 \% \mathrm{Cl}=1.31-3.31, P_{\text {heterogeneity }}=0.08\right)$ and allele \\ contrasts $\left(P=0.03,0 R=1.42,95 \% \mathrm{Cl}=1.04-1.95, \mathrm{P}_{\text {heterogeneity }}=0.0001\right)$ in the Asians, while no evidence of an association \\ between MTHFR C677T polymorphisms and PE was observed in the Caucasians. This meta-analysis suggests that the MTHFR \\ C677T polymorphism is capable of causing PE susceptibility in the Asians but not in the Caucasians.
}

Hypertension Research (2012) 35, 1129-1134; doi:10.1038/hr.2012.117; published online 23 August 2012

Keywords: methylenetetrahydrofolate reductase; MTHFR C677T; polymorphism

\section{INTRODUCTION}

Pre-eclampsia (PE) is a major pregnancy complication associated with increased blood pressure and proteinuria after 20 weeks of gestation. ${ }^{1}$ Although this disorder is a significant cause of maternal and perinatal morbidity and mortality, its etiology is not yet clear. A genetic susceptibility to PE has been well established, and genes involved with endothelial dysfunction, oxidative stress, angiogenesis and thrombophilia have been associated with $\mathrm{PE}^{2-4}$

Methylenetetrahydrofolate reductase (MTHFR) is an enzyme that catalyzes the conversion of 5, 10-methylenetetrahydrofolate to 5-methyltetrahydrofolate, a co-substrate for the transmethylation of homocysteine to methionine. Severe MTHFR deficiency is associated with hyperhomocysteinemia. The human MTHFR gene located on chromosome 1p36.3 is 1980-bp long and has a common polymorphism, C677T. This $\mathrm{C}$ to $\mathrm{T}$ transition in exon 4 results in the substitution of alanine with valine $(\mathrm{A} 222 \mathrm{~V})$ in the $\mathrm{N}$-terminal catalytic domain, which renders the enzyme thermolabile and elevates homocysteine levels. ${ }^{5}$ In clinical studies, hyperhomocysteinemia has been associated with pregnancy complications such as recurrent pregnancy loss, pregnancy-induced hypertension, placental abruption and PE. Therefore, the MTHFR C677T gene polymorphism may present a genetic risk factor for PE. ${ }^{6-9}$
To date, numerous case-control studies have been conducted to investigate the role of the C677T gene polymorphism in the development of PE, but these studies have produced conflicting or inconclusive results. The published studies have generally been restricted in sample size and ethnic diversity, and individual studies may have insufficient power to achieve a comprehensive and reliable conclusion. In 2004, Kosmasa et al. ${ }^{10}$ performed a meta-analysis to clarify the effect of the MTHFR C677T gene on the risk of PE. The meta-analysis only contained 22 studies and did not perform the subgroup analysis by ethnicity. Since 2004, there has been an expanding body of published literature assessing the association between the MTHFR C677T polymorphism and PE. To perform a more comprehensive estimate of the association between the MTHFR C677T polymorphism and the risk of PE, we conducted a meta-analysis to assess the association between the MTHFR C677T polymorphism and PE susceptibility.

\section{METHODS}

Search strategy

A comprehensive search was performed to search the electronic databases of PubMed, Web of Science, the Chinese Biomedical Database and the Chinese National Knowledge Infrastructure with the following terms: MTHFR,

${ }^{1}$ Department of Gynecology and Obstetrics, the First Affiliated Hospital of Anhui Medical University, Hefei, Anhui, China; ${ }^{2}$ Department of Gynecology and Obstetrics, the Liu'an People's Hospital, Liu'an Anhui, China and ${ }^{3}$ Department of Preventive Medicine, Wannan Medical College, Wuhu, Anhui, China 
polymorphism, PE and PE. The publication languages included only English and Chinese. The retrieved abstracts were read to identify studies examining the genotype association between the MTHFR C677T polymorphism and PE. In addition, all references cited were reviewed to identify additional studies. An upper date limit of March 2012 was applied; however, no lower date limit was set. When more than one of the same patient population was included in more than one publication, only the most recent or complete study was included in the meta-analysis.

\section{Inclusion criteria}

We reviewed the titles and abstracts of all citations and retrieved literature. The following inclusion criteria were used for literature selection: ${ }^{1}$ the publication was a case-control study referring to the association between the MTHFR C677T polymorphism and PE; ${ }^{2}$ the cases consisted of PE patients and controls consisted of normotensive pregnant women, ${ }^{3}$ there was no deviation from the Hardy-Weinberg equilibrium (HWE) among the controls; and ${ }^{4}$ the papers offered sample sizes, distributions of alleles, genotypes or other information to help us infer results. When the genotype frequency was not reported, we contacted the author to obtain the relevant information by e-mail. Major reasons for exclusion of the studies were ${ }^{1}$ lack of controls, ${ }^{2}$ duplication ${ }^{3}$ and insufficient reported data.

\section{Data extraction}

Data were extracted from each study by two independent reviewers (XP Xia and WW Chang) according to the selection criteria. Decisions were compared, and disagreements about the study selection were resolved by consensus or by involving a third reviewer (YX Cao). The following information was extracted from the literature: first author, year of publication, ethnicity of the study population, number of cases and controls and distribution of genotypes and alleles in all groups. The ethnicities were categorized as Asians, Caucasians and others.

\section{Statistical analysis}

Crude ORs with their 95\% CIs were used to assess the strength of association between the MTHFR C677T polymorphism and PE risk. The pooled ORs were calculated for the allele contrasts ( $\mathrm{T} v$ s. C), dominant genetic model (TT + TC vs. CC), recessive genetic model (TT vs. TC $+\mathrm{CC}$ ) and additive comparison (TT vs. CC). The subgroup analysis was also performed by ethnicity. In our study, two meta-analysis models were applied for dichotomous outcomes according to the results of heterogeneity tests among the individual studies: the fixed effects model (Mantel and Haenszel) ${ }^{11}$ and the random-effects model (DerSimonian and Kacker). ${ }^{12}$ The heterogeneity assumption was assessed by a $\chi^{2}$-based $Q$-test and an $I^{2}$ test. $^{13}$ The heterogeneity was considered statistically significant if $P<0.10$. The random-effects model (if $P<0.10$ ) or the fixed effects model (if $P \geqslant 0.10$ ) was used to summarize the combined odds ratio (OR). The significance of the pooled OR was determined by the $Z$-test. A $P$-value of $<0.05$ was considered significant. Deviation from the HWE $(P<0.05)$ among the control groups within each study was assessed by an exact test using an online HWE calculator (http://ihg.gsf.de/cgi-bin/hw/ hwal.pl). A possible publication bias was tested by Begg's funnel plot and Egger's test.

Analyses were performed using the Stata software version 10 (StataCorp LP, College Station, TX, USA), and Review Manager 4.2 (Cochrane Collaboration, http://www.cc-ims.net/RevMan/relnotes.htm). All $P$-values presented are twotailed.

\section{RESULTS}

\section{Study characteristics}

Through a literature search, we identified 40 potentially eligible studies. Among the 40 eligible articles, four studies were excluded because the genotype distribution in the control population deviated significantly from the HWE. ${ }^{14-17}$ There were four overlapping casecontrol studies in two publications, ${ }^{18-21}$ and we chose the most recent studies. ${ }^{19,20}$ Thus, 34 reports were eligible. ${ }^{19,20,22-53}$ One report included separate data on three hypertensive populations. ${ }^{35}$ Overall, 36 study comparisons were included in the meta-analysis (Table 1). Out of all eligible studies, 9 studies were conducted on Asians, 18 studies on Caucasians and 9 studies on others. Our final pool of eligible studies included 36 studies with 4253 cases and 4950 controls (Table 2). The characteristics of the studies included in the meta-analysis are listed in Table 1.

\section{Meta-analysis results}

Global statistical results. Table 2 lists the main results of this metaanalysis. The random-effects model was used to pool the results, as there was significant heterogeneity in 36 studies in the genetic model (Table 2). Using the random-effects model, the 677T polymorphism

Table 1 Characteristics of case-control studies included in MTHFR C677T polymorphism and $\mathrm{PE}$

\begin{tabular}{|c|c|c|c|c|c|c|c|}
\hline \multirow[b]{2}{*}{ First author (year) } & \multirow[b]{2}{*}{ Country (ethnicity) } & \multicolumn{3}{|c|}{ Cases } & \multicolumn{3}{|c|}{ Controls } \\
\hline & & $T T$ & $T C$ & $C C$ & $T T$ & $T C$ & $\mathrm{CO}$ \\
\hline Sohda (1997) & Japan (Asian) & 19 & 32 & 16 & 38 & 49 & 11 \\
\hline Chikosi (1999) & South Africa (African) & 86 & 18 & 1 & 97 & 13 & 0 \\
\hline Grandone (1999) & Italy (Caucasian) & 28 & 25 & 41 & 41 & 64 & 24 \\
\hline $\begin{array}{l}\text { O'Shaughnessy } \\
\text { (1999) }\end{array}$ & UK (Caucasian) & 138 & 114 & 31 & 51 & 37 & 12 \\
\hline Powers (1999) & USA (Caucasian) & 35 & 49 & 15 & 54 & 46 & 14 \\
\hline Kobashi (2000) & Japan (Asian) & 25 & 40 & 8 & 83 & 99 & 33 \\
\hline Laivuori (2000) & Finland (Caucasian) & 64 & 45 & 4 & 56 & 40 & \\
\hline Li (2000) & China (Asian) & 9 & 30 & 18 & 44 & 58 & 18 \\
\hline Rajkovic (2000) & Zimbabwe (African) & 142 & 28 & 1 & 151 & 32 & \\
\hline Kaiser (2001) & Australia (Caucasian) & 71 & 66 & 19 & 37 & 31 & 11 \\
\hline Kim (2001) & USA (Caucasian) & 131 & 117 & 33 & 167 & 152 & 41 \\
\hline Lachmeijer (2001) & $\begin{array}{l}\text { Netherlands } \\
\text { (Caucasian) }\end{array}$ & 22 & 21 & 4 & 58 & 51 & 11 \\
\hline Raijmakers (2001) & $\begin{array}{l}\text { Netherlands } \\
\text { (Caucasian) }\end{array}$ & 72 & 74 & 21 & 205 & 162 & 36 \\
\hline Watanabe (2001) & Japan (Asian) & 40 & 59 & 34 & 89 & 103 & 32 \\
\hline Morrison (2002) & UK (Caucasian) & 169 & 193 & 42 & 81 & 66 & 17 \\
\hline Prasmusinto (2002) & Indonesian (Asian) & 34 & 6 & 1 & 22 & 5 & \\
\hline Prasmusinto (2002a) & Croatian (Caucasian) & 11 & 12 & 2 & 18 & 15 & \\
\hline Prasmusinto (2002b) & German (Caucasian) & 7 & 7 & 1 & 12 & 15 & 7 \\
\hline De Maat (2004) & $\begin{array}{l}\text { Netherlands } \\
\text { (Caucasian) }\end{array}$ & 78 & 59 & 20 & 63 & 75 & 19 \\
\hline Perez-Mutul (2004) & Mexica (Mexican) & 33 & 66 & 49 & 36 & 80 & 61 \\
\hline Pegoraro (2004) & South Africa (African) & 232 & 38 & 1 & 298 & 38 & \\
\hline Williams (2004) & Peru (South American) & 37 & 61 & 25 & 62 & 85 & 30 \\
\hline Yilmaz (2004) & Turkey (Caucasian) & 29 & 28 & 7 & 24 & 17 & \\
\hline Also-Rallo (2005) & Spain (Caucasian) & 11 & 24 & 8 & 37 & 56 & 29 \\
\hline Davalos (2005) & Mexica (Mexican) & 13 & 14 & 6 & 24 & 27 & 11 \\
\hline Dalmaz (2006) & Brazil (Mixed) & 31 & 27 & 17 & 76 & 51 & 18 \\
\hline Jaaskelainen (2006) & Finland (Caucasian) & 78 & 43 & 12 & 64 & 42 & \\
\hline Dusse (2007) & Brazil (Mixed) & 16 & 12 & 2 & 45 & 31 & 7 \\
\hline Zhang (2007) & China (Asian) & 12 & 21 & 20 & 10 & 30 & 9 \\
\hline Nagy (2007) & Hungary (Caucasian) & 49 & 43 & 9 & 32 & 35 & 6 \\
\hline Canto (2008) & Mexica (Mixed) & 36 & 66 & 23 & 61 & 131 & 82 \\
\hline Muetze (2008) & German (Caucasian) & 30 & 34 & 7 & 35 & 29 & \\
\hline Zhang (2008) & China (Asian) & 22 & 21 & 7 & 29 & 8 & \\
\hline Shen (2009) & China (Asian) & 12 & 35 & 14 & 30 & 21 & \\
\hline Stiefel (2009) & Spain (Caucasian) & 27 & $157^{a}$ & & 21 & $113^{\mathrm{b}}$ & \\
\hline Aggarwal (2011) & India (Asian) & 160 & 33 & 7 & 134 & 58 & \\
\hline
\end{tabular}

Abbreviation: PE, pre-eclampsia.

${ }^{\mathrm{T} C}+\mathrm{CC}$ in the $\mathrm{PE}$ group.

${ }^{\mathrm{D}} \mathrm{TC}+\mathrm{CC}$ in the control group. 
Table 2 Summary ORs and 95\% Cl of MTHFR C677T polymorphism and PE

\begin{tabular}{|c|c|c|c|c|c|}
\hline Analysis model & $\begin{array}{l}\text { Populations } \\
\text { (study no.) }\end{array}$ & OR $(95 \% \mathrm{Cl})$ & $\mathrm{P}_{O R}$ & $\mathrm{I}^{2}(\%)$ & $\mathrm{P}_{H}$ \\
\hline \multirow[t]{4}{*}{ T vs. C } & Total $^{35}$ & $1.11(0.99-1.25)^{\mathrm{a}}$ & 0.08 & 59.8 & $<0.0001$ \\
\hline & Caucasian $^{17}$ & $1.02(0.89-1.18)^{a}$ & 0.73 & 48.6 & 0.01 \\
\hline & Asian 9 & $1.42(1.04-1.95)^{\mathrm{a}}$ & 0.03 & 74.2 & 0.0001 \\
\hline & Others $^{9}$ & $1.06(0.88-1.29)^{a}$ & 0.54 & 43.8 & 0.08 \\
\hline \multirow[t]{4}{*}{$\mathrm{TT}$ vs. $(\mathrm{TC}+\mathrm{CC})$} & Total $^{35}$ & $1.19(0.99-1.44)^{\mathrm{a}}$ & 0.07 & 38.9 & 0.01 \\
\hline & Caucasian $^{17}$ & $1.07(0.84-1.37)^{\mathrm{a}}$ & 0.58 & 32.9 & 0.09 \\
\hline & Asian 9 & $1.76(1.33-2.33)$ & $<0.0001$ & 18.8 & 0.28 \\
\hline & Others $^{9}$ & $0.95(0.74-1.23)$ & 0.69 & 29.5 & 0.18 \\
\hline \multirow[t]{4}{*}{$(\mathrm{TT}+\mathrm{TC})$ vs. $\mathrm{CC}$} & Total ${ }^{36}$ & $1.14(1.01-1.29)^{\mathrm{a}}$ & 0.04 & 38.3 & 0.01 \\
\hline & Caucasian $^{18}$ & $1.08(0.96-1.22)$ & 0.21 & 0 & 0.78 \\
\hline & Asian 9 & $1.52(0.94-2.46)^{\mathrm{a}}$ & 0.09 & 77.0 & $<0.0001$ \\
\hline & Others $^{9}$ & $1.09(0.90-1.31)$ & 0.40 & 0 & 0.51 \\
\hline \multirow[t]{4}{*}{ TT vs. CC } & Total $^{35}$ & $1.25(1.02-1.54)^{\mathrm{a}}$ & 0.03 & 36.8 & 0.02 \\
\hline & Caucasian $^{17}$ & $1.12(0.92-1.37$ & 0.27 & 0 & 0.52 \\
\hline & Asian 9 & $2.09(1.31-3.31)^{\mathrm{a}}$ & 0.002 & 42.4 & 0.08 \\
\hline & Others $^{9}$ & $0.99(0.73-1.33)$ & 0.93 & 35.2 & 0.14 \\
\hline
\end{tabular}

Abbreviations: $\mathrm{Cl}$, confidence interval; OR, odds ratio; $\mathrm{PE}$, pre-eclampsia.

$I^{2}(\%)$ and $P_{\mathrm{H}}$ value for heterogeneity.

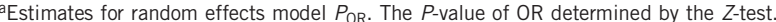

had an effect of increasing the PE risk under the additive comparison $(P=0.03, \quad \mathrm{OR}=1.25,95 \%$ confidence interval $(\mathrm{CI})=1.02-1.54$, $\left.P_{\text {heterogeneity }}=0.02\right)$ and the dominant genetic model $(P=0.04$, $\left.\mathrm{OR}=1.14,95 \% \mathrm{CI}=1.01-1.29, P_{\text {heterogeneity }}=0.01\right)$. There was no significant association between the 677T polymorphism and PE risk under the recessive genetic model and the allele contrasts (Table 2).

Stratification analysis. We only performed the subgroup analysis of ethnicity on the Asian and Caucasian populations. The results showed that the MTHFR C677T polymorphism increased the PE risk for the recessive genetic model $(P<0.0001, \mathrm{OR}=1.76,95 \% \mathrm{CI}=1.33-2.33$, $\left.P_{\text {heterogeneity }}=0.28\right)$, the additive comparison $(P=0.002, \mathrm{OR}=2.09$, $\left.95 \% \mathrm{CI}=1.31-3.31, P_{\text {heterogeneity }}=0.08\right)$ and allele contrasts $(P=0.03$, $\left.\mathrm{OR}=1.42,95 \% \mathrm{CI}=1.04-1.95, P_{\text {heterogeneity }}=0.0001\right)$ in the Asians, whereas no evidence of an association between MTHFR C677T polymorphisms and PE was observed in the Caucasians (Table 2 and Figure 1). The sensitivity analysis showed that the Aggarwal et al. study was the origin of the heterogeneity. When this article was excluded, the heterogeneity in all models disappeared, and an obvious association was noted for Asians under the dominant genetic model $\left(P=0.002, \mathrm{OR}=1.79,95 \% \mathrm{CI}=1.25-2.58, P_{\text {heterogeneity }}=0.35\right)$.

Publication bias. As shown in Figure 2, the shape of the funnel plot did not reveal obvious asymmetry under the recessive genetic model. Egger's test was then used to provide statistical evidence of funnel plot symmetry. The results still did not suggest any evidence of a publication bias (data not shown).

\section{DISCUSSION}

During pregnancy, there are several hypertensive disorders that complicate gestation, ranging from mild and transient hypertension to severe PE/eclampsia syndrome. ${ }^{54} \mathrm{PE}$ is a hypertensive disorder that is characterized by high blood pressure and proteinuria, and it occurs in the second or third trimester of pregnancy with a particularly high incidence in the Caucasian population. ${ }^{1,7,55}$ It is known that a woman who has a pregnancy complicated by PE has an increased risk of hypertension, ischemic heart disease and stroke in the 10-15 years after the pregnancy. ${ }^{56}$ As PE affects $2-5 \%$ of pregnancies, 1.2-3 million people in the United kingdom and 6-15 million in the United States of America are offspring of pregnancies complicated by PE. ${ }^{57,58}$

$\mathrm{PE}$ is a complex, multifactorial pregnancy-specific condition involving genetic, environmental and behavioral factors. ${ }^{59}$ Hyperhomocysteinemia has been associated with the development of PE, and the most common polymorphism associated with this condition is the thermolabile $677 \mathrm{~T}$ allele of the MTHFR gene, which results in reduced enzyme activity and impaired homocysteine/folate metabolism, leading to moderate hyperhomocysteinemia. ${ }^{5,60,61}$ The literature on the relationship between the MTHFR C677T polymorphism and PE risk is replete with small studies reporting controversial findings, and no clear consensus has been reached. We therefore performed a meta-analysis to form a more precise estimation of the association of the MTHFR C677T polymorphism and PE risk.

Our meta-analysis was based on 36 studies with 4253 cases and 4950 controls that evaluated the association between the MTHFR C677T gene polymorphism and PE. In the present studies, we detected a significant association between the MTHFR C677T polymorphism and PE risk in all subjects; however, when we made a stratification analysis of ethnicity, a significant association could only be found in the Asians and not in the Caucasians. This finding indicates that the potentially functional MTHFR C677T polymorphism may have a low penetrance role in PE susceptibility in an ethnicity-specific manner. The between-study heterogeneity existed for Asians. The sensitivity analysis showed that the Aggarwal et al. ${ }^{53}$ study was the origin of the heterogeneity, and when this article was excluded, a significant association could still be found. Our results were consistent with the previously published meta-analysis by Kosmas et al., ${ }^{10}$ which showed small, but statistically significant, associations between the MTHFR C677T polymorphism and PE in the overall population. However, their meta-analysis did not cover Chinese databases (Chinese Biomedical Database, Chinese National Knowledge Infrastructure and Wan Fang) and did not perform subgroup analyses on the different types of study populations.

Theoretically, the MTHFR C677T polymorphism could cause hyperhomocysteinemia and may increase the risk of PE. However, in our meta-analysis, the MTHFR C677T allele increased the risk of $\mathrm{PE}$ in the Asians but not in the Caucasians. There are numerous possible reasons for the same polymorphism having a different role in different ethnic populations. First, an ethnic variant in the frequency of the MTHFR C677T mutation was demonstrated in various populations. The frequency of the 677T allele ranges from 6 to $10.3 \%$ in the African populations, from 32.2 to $44 \%$ among the Caucasian populations, and from 30.5 to $42 \%$ in the East Asian populations. ${ }^{62,63}$ Clinical heterogeneity may also explain the discrepancy. There are many other factors that may affect Hcy levels (for example, diet, alcohol, smoking and drugs). MTHFR, folate and vitamin B12 jointly participate in the metabolism of $\mathrm{Hcy}$, and therefore the influence of the MTHFR C677T polymorphism on Hcy levels is most prominent in subjects with low folate and vitamin B12 concentrations. ${ }^{64}$

The characteristics of a meta-analysis are to combine comparable studies and to increase the sample size and statistical power, thus revealing a more compelling result. However, a meta-analysis has confounding factors such as publication bias, method of sampling, 


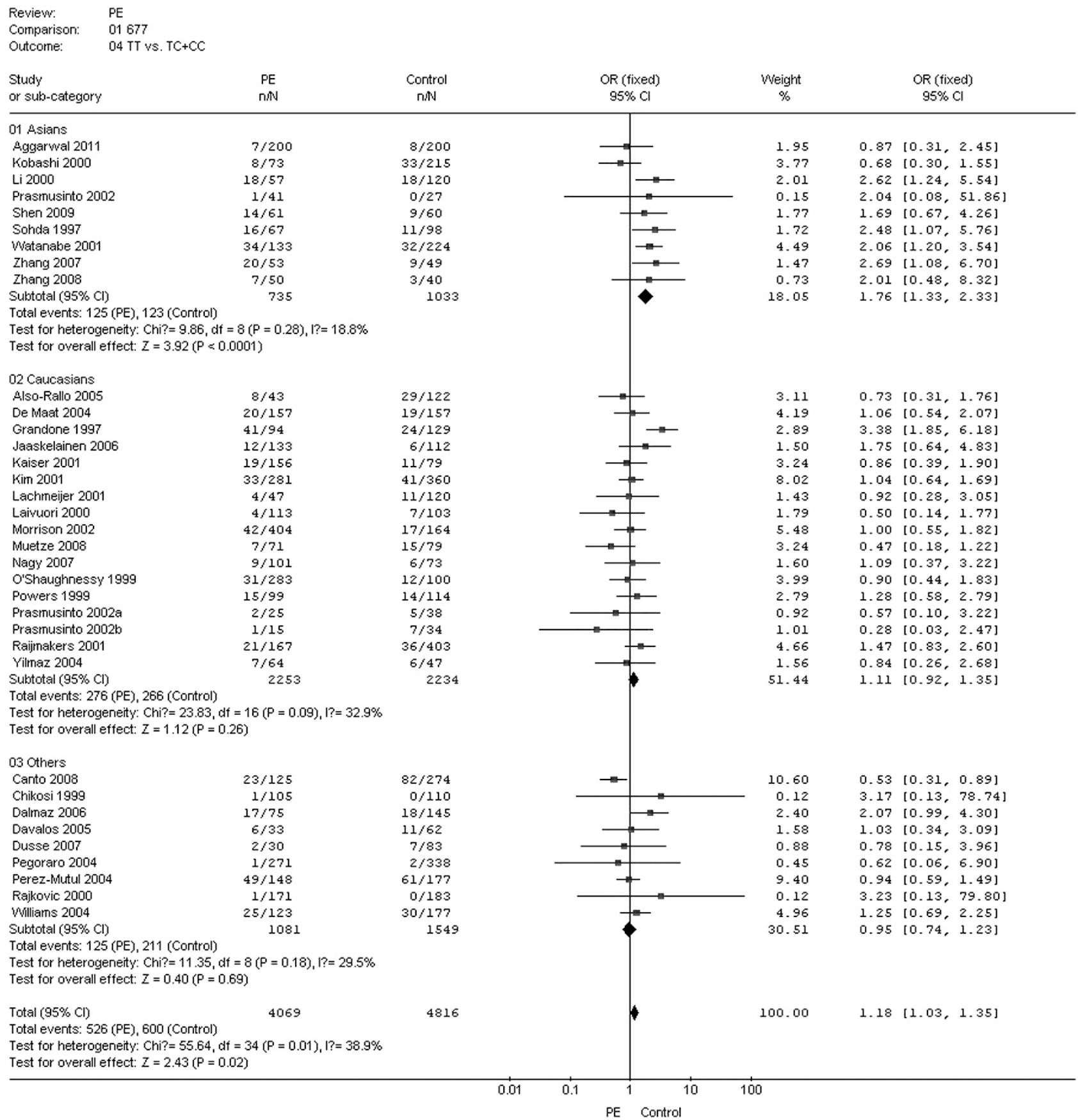

Figure 1 Forest plot for the association between MTHFR C677T polymorphisms and PE for the recessive genetic model (TT vs. TC + CC). Each study is shown by the point estimate of the OR and the $95 \% \mathrm{Cl}$ for the OR. A full color version of this figure is available at the Hypertension Research journal online.

varying genetic backgrounds of subjects, and varying protocols and quality of analysis. We followed the inclusion and exclusion criteria strictly to reduce the selection bias. The funnel plot and Egger's linear regression test were used to assess the publication bias. The HWE test for the distribution of the genotypes in the control groups suggested that there were no significantly different genetic backgrounds among the participants.

To some extent, a number of limitations have affected the objectivity of the conclusions and should be considered when interpreting the results. (1) Given that only published studies were included in the meta-analysis, a publication bias may have occurred, even though it was not found when performing the statistical test. (2) A language bias may have occurred because this meta-analysis only contained Chinese and English language literature. However, some relevant articles in other languages were published in specific journals but were not found in the international journals. (3) In this study, we could not obtain information from some of the studies on folate and vitamin B12 levels, which may affect the associations between the MTHFR C677T polymorphism and PE. 


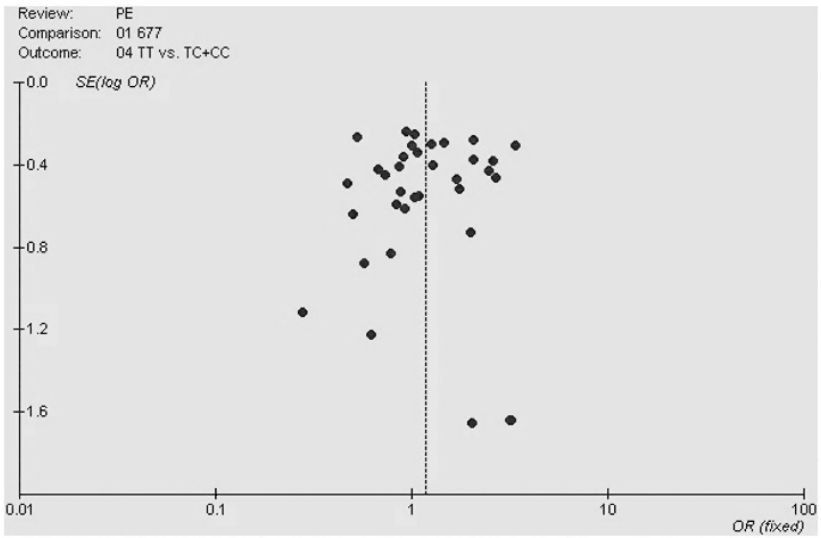

Figure 2 Funnel plot analysis to detect a publication bias for the recessive genetic model (TT vs. TC $+\mathrm{CC}$ ) of the MTHFR C677T polymorphism in the overall analysis. Each point represents a separate study for the indicated association. OR, odds ratio. A full color version of this figure is available at the Hypertension Research journal online.

In conclusion, our meta-analysis suggests that the MTHFR C677T polymorphism may contribute to individual susceptibility to $\mathrm{PE}$ in the Asians; however, there is insufficient evidence to confirm this association in the Caucasians. The potentially functional MTHFR C677T polymorphism may have a low penetrance role in $\mathrm{PE}$ susceptibility in an ethnicity-specific manner. In terms of PE with multifactorial etiology, further studies or complete case-control studies are warranted, especially those stratified by ethnic backgrounds, environmental exposures or other risk factors, to clarify the possible roles of the MTHFR C677T polymorphism in the pathogenesis of PE.

\section{CONFLICT OF INTEREST}

The authors declare no conflict of interest.

\section{ACKNOWLEDGEMENTS}

We thank Dr Murphy RP for providing additional information and data on his study. We also thank the editors of this manuscript and Wei-wei Chang for providing advice for the writing and revision of the manuscript.

1 Sibai B, Dekker G, Kupferminc M. Pre-eclampsia. Lancet 2005; 365: 785-799.

2 Chappell S, Morgan L. Searching for genetic clues to the causes of pre-eclampsia. Clin Sci 2006; 110: 443-458.

3 Goddard KA, Tromp G, Romero R, Olson JM, Lu Q, Xu Z, Parimi N, Nien JK, Gomez R, Behnke E, Solari M, Espinoza J, Santolaya J, Chaiworapongsa T, Lenk GM, Volkenant K, Anant MK, Salisbury BA, Carr J, Lee MS, Vovis GF, Kuivaniemi H. Candidate gene association study of mothers with pre-eclampsia, and their infants, analyzing 775 SNPs in 190 genes. Hum Hered 2007; 63: 1-16.

4 Parimi N, Tromp G, Kuivaniemi H, Nien JK, Gomez R, Romero R, Goddard KA. Analytical approaches to detect maternal/fetal genotype incompatibilities that increase risk of pre-eclampsia. BMC Med Genet 2008; 9: 60 .

5 Frosst P, Blom HJ, Milos R, Goyette P, Sheppard CA, Matthews RG, Boers GJH, den Heijer M, Kluijtmans LAJ, van den Heuve LP, Rozen RA. candidate genetic risk factor for vascular disease: a common mutation in methylenetetrahydrofolate reductase. Nat Genet 1995; 10: 111-113.

6 Nelen WL, Blom HJ, Steegers EA, den Heijer M, Eskes TK. Hyperhomocysteinemia and recurrent early pregnancy loss: a meta-analysis. Fertil Steril 2000; 74: 1196-1199.

7 Kupferminc MJ. Thrombophilia and pregnancy. Curr Pharm Des 2005; 11: 735-748.

8 Eskes TK. Clotting disorders and placental abruption: homocysteine-a new risk factor. Eur J Obstet Gynecol Reprod Biol 2001; 95: 206-212.

9 Vollset SE, Refsum H, Irgens LM, Emblem BM, Tverdal A, Gjessing HK, Monsen AL, Ueland PM. Plasma total homocysteine, pregnancy complications, and adverse pregnancy out-comes: the Hordaland Homocysteine study. Am J Clin Nutr 2000; 71 962-968.
10 Kosmasa IP, Tatsioni A, Ioannidis JPA. Association of C677T polymorphism in the methylenetetrahydrofolate reductase gene with hypertension in pregnancy and preeclampsia: a meta-analysis. J Hypertens 2004; 22: 1655-1662.

11 Mantel N, Haenszel W. Statistical aspects of the analysis of data from retrospective studies of disease. J Natl Cancer Inst 1959; 22: 719-748.

12 DerSimonian R, Kacker R. Random-effects model for meta-analysis of clinical trials: an update. Contemp Clin Trials 2007; 28: 105-114.

13 Higgins JP, Thompson SG. Quantifying heterogeneity in a meta-analysis. Stat Med 2002; 21: 1539-1558.

14 Rigo J, Nagy B, Fintor L, Tanyi J, Beke A, Karadi I, Papp Z. Maternal and neonatal outcome of preeclamptic pregnancies: the potential roles of factor $\mathrm{V}$ Leiden mutation and 5,10 methylenetetrahydrofolate reductase. Hypertens Pregn 2000; 19: $163-172$.

15 Livingstone JC, Barton JR, Park V, Haddad B, Philips O, Sibai BM. Maternal and fetal inherited thrombophilias are not related to the development of severe preeclampsia. Am J Obstet Gynecol 2001; 185: 153-157.

16 Wang SM, Wang LG, Liu XJ, Wu AH, Yu JC, Shi H. Investigation on the association between MTHFR gene C677T polymorphism and pre - eclampsia. Maternal and Child Health Care of China 2008; 23: 552-554.

17 Murphy RP, Donoghue C, Nallen RJ, D'Mello M, Regan C, Whitehead AS, Fitzgerald DJ. Prospective evaluation of the risk conferred by factor $\mathrm{V}$ Leiden and thermolabile methylenetetrahydrofolate reductase polymorphisms in pregnancy. Arterioscler Thromb Vasc Biol 2000; 20: 266-270.

18 Kaiser T, Brennecke SP, Moses EK. Methylenetetrahydrofolate reductase polymorphisms are not a risk factor for pre-eclampsia/eclampsia in Australian women. Gynecol Obstet Invest 2000; 50: 100-102.

19 Kaiser T, Brennecke SP, Moses EK. C677T methylenetetrahydrofolate reductase polymorphism is not a risk factor for pre-eclampsia/eclampsia among Australian women. Hum Hered 2001; 51: 20-22.

20 Raijmakers MT, Zusterzeel PL, Steegers EA, Peters WH. Hyperhomocys-teinaemia: a risk factor for preeclampsia? Eur J Obstet Gynecol Reprod Biol 2001; 95: 226-228.

21 Zusterzeel PL, Visser W, Blom HJ, Peters WH, Heil SG, Steegers EA. Methylenetetrahydrofolate reductase polymorphisms in pre-eclampsia and the HELLP syndrome. Hypertens Pregnancy 2000; 19: 299-307.

22 Sohda S, Arinami T, Hamada H, Yamada N, Hamaguchi H, Kubo T. Methylenetetrahydrofolate reductase polymorphism and pre-eclampsia. J Med Genet 1997; 34: 525-526.

23 Grandone E, Margaglione M, Colaizzo D, Cappucci G, Paladini D, Martinelli P, Montanaro S, Pavone G, Di Minno G. The factor V Leiden, C.T MTHFR polymorphism and genetic susceptibility to pre-eclampsia. Thromb Haemost 1997. 77: 1052-1054

24 Chikosi AB, Moodley J, Pegoraro RJ, Lanning PA, Rom L. 5,10 methylenetetrahydrofolate reductase polymorphism in black South African women with pre-eclampsia. Br J Obstet Gynaecol 1999; 106: 1219-1220.

25 O'Shaughnessy KM, Fu B, Ferraro F, Lewis I, Downing S, Morris NH. F actor V Leiden and thermolibile methylenetetrahydrofolate reductase gene variants in an East Anglian preeclampsia cohort. Hypertension 1999; 33: 1338-1341.

26 Powers RW, Minich LA, Lykins DL, Ness RB, Crombleholme WR, Roberts JM. Methylenetetrahydrofolate reductase polymorphism,folate, and susceptibility to preeclampsia. J Soc Gynecol Investig 1999; 6: 74-79.

27 Kobashi G, Yamada H, Asano T, Nagano S, Hata A, Kishi R, Fujimoto S, Kondo K. Absence of association between a common mutation in the methylenete-trahydrofolate reductase gene and preeclampsia in Japanese women. Am J Med Genet 2000; 93 : $122-125$.

28 Laivuori H, Kaaja R, Ylikorkala O, Hiltunen T, Kontula K. $677 \mathrm{C} \rightarrow$ T polymorphism of the methylenetetrahydrofolate reductase gene and pre-eclampsia. Obstet Gynecol 2000: 96: 277-280.

29 Li K, Zheng D, Xue Y, Sun Y, Chen L, Guo J, Zhang G, Li P. The common C677T polymorphism in the methylenetetrahydrofolate reductase gene is associated with neural tube defects and preeclampsia. Zhonghua Yi Xue Yi Chuan Xue Za Zhi 2000; 17: 76-78.

30 Rajkovic A, Mahomed K, Rozen R, Malinow MR, King IB, Williams MA. Methylenetetrahydrofolate reductase $677 \mathrm{C} \rightarrow \mathrm{T}$ polymorphism, plasma folate, vitamin B (12) concentrations, and risk of preeclampsia among black African women from Zimbabwe. Mol Genet Metab 2000; 69: 33-39.

31 Kim YJ, Williamson RA, Murray JC, Andrews J, Pietscher JJ, Peraud PJ, Merrill DC. Genetic susceptibility to preeclampsia: roles of cytosineto-thymine substitution at nucleotide 677 of the gene for methylenete-trahydrofolate reductase, 68-base pair insertion at nucleotide 844 of the gene for cystathionine beta-synthase, and factor $\mathrm{V}$ Leiden mutation. Am J Obstet Gynecol 2001; 184: 1211-1217.

32 Lachmeijer AM, Arngrimsson R, Bastiaans EJ, Pals G, ten Kate LP, de Vries JI, Kostense PJ, Aarnoudse JG, Dekker GA. Mutations in the gene for methylenetetrahydrofolate reductase, homocysteine levels, and vitamin status in women with a history of preeclampsia. Am J Obstet Gynecol 2001; 184: 394-402.

33 Watanabe H, Hamada H, Yamakawa-Kobayashi K, Yoshikawa H, Arinami T. Evidence for an association of the R485K polymorphism in the coagulation factor $\mathrm{V}$ gene with severe preeclampsia from screening 35 polymorphisms in 27 candidate genes. Thromb Haemost 2001; 86: 1594-1595.

34 Morrison ER, Miedzybrodzka ZH, Campbell DM, Haites NE, Wilson BJ, Watson MS, Greaves M, Vickers MA. Prothrombotic genotypes are not associated with preeclampsia and gestational hypertension: results from a large population-based study and systematic review. Thromb Haemost 2002; 87: 779-785. 
35 Prasmusinto D, Skrablin S, Hofstaetter C, Fimmers R, van der Ven K. The methylenetetrahydrofolate reductase $677 \mathrm{C} \rightarrow T$ polymorphism and pre-eclampsia in two populations. Obstet Gynecol 2002; 99: 1085-1092.

36 De Maat MP, Jansen MW, Hille ET, Vos HL, Bloemenkamp KW, Buitendijk S, Helmerhorst FM, Wladimiroff JW, Bertina RM, De Groot CJ. Preeclampsia and its interaction with common variants in thrombophilia genes. J Thromb Haemost 2004; 2: 1588-1593.

37 Perez-Mutul J, Gonzalez-Herrera L, Sosa-Cabrera T, Martínez-Olivares R. A mutation in the 5, 10-methylenetetrahydrofolate reductase gene is not associated with preeclampsia in women of southeast Mexico. Arch Med Res 2004; 35: 231-234.

38 Pegoraro RJ, Chikosi A, Rom L, Roberts C, Moodley J. Methylenetetrahydrofolate reductase gene polymorphisms in black South Africans and the association with preeclampsia. Acta Obstet Gynecol Scand 2004; 83: 449-454.

39 Williams MA, Sanchez SE, Zhang C, Bazul V. Methylenetetrahydrofolate reductase 677 $\mathrm{C} \rightarrow \mathrm{T}$ polymorphism and plasma folate in relation to pre-eclampsia risk among Peruvian women. J Matern Fetal Neonatal Med 2004; 15: 337-344.

40 Yilmaz H, Unlüçerçi Y, Gürdöl F, Isbilen E, Isbir T. Association of pre-eclampsia with hyperhomocysteinaemia and methylenetetrahydrofolate reductase gene C677Tpolymorphism in a Turkish population. Aust N Z J Obstet Gynaecol 2004; 44 423-427.

41 Also-Rallo E, Lopez-Quesada E, Urreizti R, Vilaseca MA, Lailla JM, Balcells S, Grinberg D. Polymorphisms of genes involved in homocysteine metabolism in preeclampsia and in uncomplicated pregnancies. Eur J Obstet Gynecol Reprod Biol 2005; 120 45-52.

42 Davalos IP, Moran MC, Martinez-Abundis E, González-Ortiz M, Flores-Martínez SE, Machorro V, Sandoval L, Figuera LE, Mena JP, Oliva JM, Tlacuilo-Parra JA, SánchezCorona JSalazar-Páramo M. Methylenetetrahydrofolate reductase C677T polymorphism and Factor $\mathrm{V}$ Leiden variant in Mexican women with preeclampsia/eclampsia. Blood Cells Mol Dis 2005; 35: 66-69.

43 Dalmaz CA, Santos KG, Botton MR, Tedoldi CL, Roisenberg I. Relationship between polymorphisms in thrombophilic genes and preeclampsia in a Brazilian population. Blood Cells Mol Dis 2006; 7: 107-110.

44 Jääskeläinen E, Keski-Nisula L, Toivonen S, Romppanen EL, Helisalmi S, Punnonen K, Heinonen S. MTHFR C677T polymorphism is not associated with placental abruption or preeclampsia in Finnish women. Hypertens Pregnancy 2006; 25: 73-80.

45 Dusse LM, Carvalho MG, Braganca WF, Paiva SG, Godoi LC, Guimarães DA, Fernandes AP. Inherited thrombophilias and pre-eclampsia in Brazilian women. Eur J Obstet Gynecol Reprod Biol 2007; 34: 20-23.

46 Nagy B, Hupuczi P, Papp Z. High frequency of methylenetetrahydrofolate reductase $677 T T$ genotype in Hungarian HELLP syndrome patients determined by quantitative real-time PCR. J Hum Hypertens 2007; 21: 154-158.

47 Zhang ZH, Zhang RJ, Liu AM, Xu X, Liu ZH. Study on eNOS gene and MTHFR gene polymorphisms in preeclampsia. J Birth Health Hered 2007; 15: 21-23.

48 Canto $\mathrm{P}$, Canto-Cetina T, Juárez-Velázquez R, Rosas-Vargas $\mathrm{H}$, Rangel-Villalobos $\mathrm{H}$, Canizales-Quinteros S, Velázquez-Wong AC, Villarreal-Molina MT, Fernández G, CoralVázquez R. Methylenetetrahydrofolate reductase C677T and glutathione S-transferase
P1 A313G are associated with a reduced risk of preeclampsia in Maya-Mestizo women. Hypertens Res 2008; 31: 1015-1019.

49 Muetze S, Leeners B, Ortlepp JR, Kuse S, Tag CG, Weiskirchen R, Gressner AM, Rudnik-Schoeneborn S, Zerres K, Rath W. Maternal factor V Leiden mutation is associated with HELLP syndrome in Caucasian women. Acta Obstet Gynecol Scand 2008; 87: 635-642.

50 Zhang $X Y$, Sun $D$, Sun J. The relationship between plasma homocysteine and preeclampsia. J Perinat Med 2008; 114: 245-248.

51 Shen XN, Huang YP, Tang SH, Zhang CL, Chen WS. The relationship between the polymorphism of MTHFR gene and pre-eclampsia. J Pract Obstet Gynecol 2009; 25: 236-238.

52 Stiefel P, Miranda ML, Bellido LM, Luna J, Jiménez L, Pamies E, de Frutos PG, Villar J. Genotype of the CYBA promoter $-930 \mathrm{~A} / \mathrm{G}$, polymorphism C677T of the MTHFR and APOE genotype in patients with hypertensive disorders of pregnancy: an observational study. Med Clin, 2009; 133: 657-661.

53 Aggarwal S, Dimri N, Tandon I, Agarwal S. Pre-eclampsia in North Indian women: the contribution of genetic polymorphisms. J Obstet Gynaecol Res 2011; 37: 1335-1341.

54 Report of the National High Blood Pressure Education Program Working Group on high blood pressure in pregnancy. Am J Obstet Gynecol 2000; 183: S1-S22.

55 Khan KS, Wojdyla D, Say L, Gulmezoglu AM, Van Look PF. WHO analysis of causes of maternal death: A systematic review. Lancet 2006; 367: 1066-1074.

56 McDonald SD, Malinowski A, Zhou Q, Yusuf S, Devereaux PJ. Cardiovascular sequelae of preeclampsia/eclampsia: a systematic review and meta-analyses. Am Heart J 2008 156: 918-930.

57 Wen SW, Chen XK, Rodger M, Rennicks White R, Yang Q, Smith GN, Sigal RJ, Perkins $\mathrm{SL}$, Walker MC. Folic acid supplementation in early second trimester and the risk of preeclampsia. Am J Obstet Gynecol 2008; 198: e41-e47.

58 Steegers EAP, von Dadelszen P, Duvekot JJ, Pijnenborg R. Pre-eclampsia. Lancet 2010; 376: 631-644.

59 López-Jaramillo P, Casas JP, Serrano N. Pre-eclampsia:from epidemiological observations to molecular mechanisms. Braz J Med Biol Res 2001; 34: 1227-1235.

60 Lopez-Quesada E, Vilaseca MA, Lailla JM. Plasma total homocysteine in uncomplicated pregnancy and in preec-lampsia. Eur J Obstet Gynecol Reprod Biol 2003 108: 45-49.

61 Fletcher 0 , Kessling AM. MTHFR association with arteriosclerotic vascular disease? Hum Genet 1998; 103: 11-21.

62 Rosenberg N, Murata M, Ikeda Y, Opare-Sem O, Zivelin A, Geffen E, Seligsohn U. The frequent 5,10-methylenetetrahydrofolate reductase $\mathrm{C677T}$ polymorphismis associated with a common haplotype in whites, Japanese, and Africans. Am J Hum Genet 2002; 70: 758-762.

63 Sadewa AH, Sutomo RS, Hayashi C, Lee MJ, Ayaki H, Sofro AS, Matsuo M, Nishio H. The C677T mutation in the methylenetetrahydrofolate reductase gene among the Indonesian Javanese population. Kobe J Med Sci 2002; 48: 137-144.

64 Ueland PM, Hustad S, Schneede J, Refsum H, Vollset SE. Biological and clinical implications of the MTHFR C677T polymorphism. Trends Pharmacol Sci 2001; 22: 195-201. 